administrative agency ${ }^{80}$ The prime requirement is that the standard of conduct by which the agency is to guide its actions must be reasonably definite and certain. ${ }^{8 x}$

The legislative standard prescribed in the various correction acts and in Senate Bill 63 is that of public safety..$^{8_{2}}$ Admittedly this is a vague standard, but the nature of corrective activities negatives the possibility of a more definite rule of conduct. In view of the purpose and aims of youth correction legislation, the standard of public safety seems adequate and sufficiently certain. Only a very conservative court would condemn such legislation as an unlawful delegation of legislative power.

In all probability the strongest sources of opposition to youth correction legislation in Illinois are the judges who have resented any attempts to decrease their power, ${ }^{83}$ and the local communities which resent an increase of the power of central state agencies and a decrease of their functions in dealing with the problem of delinquency on a local level. It is true that a youth correction act would reduce the power of the judge over sentencing. However, in view of the present application of the indeterminate sentence law to youthful offenders under which sentences for identical crimes vary depending upon the whims and irrationalities of the judge, it would appear that such a reduction in judicial power would be highly desirable. The fear by communities of a reduced role in delinquency prevention has not materialized. The contrary is apparent in those states which have adopted youth correction legislation.

In view of the present disposition of youth offenders in Dlinois-one which is highly inadequate-and in view of the strides and success of youth correction in other states, the time again is ripe for the introduction of a youth correction act to the legislature.

\title{
PROMISSORY ESTOPPEL-A BASIS FOR ENFORCEMENT OF GOVERNMENTAL PROMISES BY THIRD PARTIES
}

Although a subcontractor engaged upon a building contract normally looks first to the contractor for any compensation due him, experience has often demonstrated the practical inadequacy of this contractual remedy. The improvidence of the contractor and the lack of any contractual relationship with the owner frequently have left the subcontractor unable to obtain compensation either for labor and materials expended, or for damages sustained in connection

80 People v. Roth, 249 Ill. 532, 94 N.E. 953 (I933). Compare People v. Wilson Oil Co., 364 Ill. 406, 4 N.E. 2 d 847 (1937); Boshuizen v. Thompson and Taylor Co., 360 Ill. I60, I95 N.E. 625 (1935); People v. Yonker, 35x Ill. I39, I84 N.E. 228 (I932); People v. Beekman \& Co., 347 IIl. 92 , I79 N.E. 435 (1932).

8 Tbid.

$$
{ }^{2} \text { Senate Bill 63, \& } 28 \text { (1947). }
$$

${ }^{8}$ Senator Marovitz, Transcript, Midwest Forum of the Air, April I3, r947, p. 6 et seq.; cf. Judge Wallace, N.Y. Times $\S \mathrm{I}$, p. I2, col. 6-7 (March I3, I943). 
with the work. Almost every state now provides a statutory mechanics' lien which makes available that property which is the subject matter of the contract as an additional measure of security to the subcontractor. ${ }^{x}$ However, as a lien cannot be enforced with respect to public property, ${ }^{2}$ subcontractors engaged upon a federal, state or municipal project remain outside the benefit of this remedial legislation.

Congress has to some extent corrected the situation with respect to work on federal projects by providing that contractors with the United States must furnish a bond for the protection of subcontractors and materialmen, ${ }^{3}$ but the statute is effective only as to their outlays for labor and materials necessary for the performance of the prime contract and within the contemplation of the parties to it. 4 Clearly outside the scope of the Act are claims for damages occasioned by breaches of the prime contract by the government. ${ }^{5}$ These are governed solely by decisions in the United States Court of Claims and the Supreme Court under the authority of a statute outlining the general contractual liability of the government. ${ }^{6}$

Claims against the United States for damages sustained by subcontractors have come before these courts in two forms. Subcontractors have sued the government directly, in which circumstance the courts have usually rejected these claims as lacking foundation upon a contract with the United States. ${ }^{7}$ However, when the subcontractors' damages have been presented in the form of claims by the contractor in behalf of the subcontractors, the courts have generally allowed them, ${ }^{8}$ presumably on the theory that the amounts represent the extent to which the contractor has been damaged by the government's breach of the prime contract. Contrary results, then, have been the consequence of dissimilarities which appear to be essentially procedural.

${ }^{x}$ Armour v. Western Const. Co., 36 Wash. 529, 78 Pac. Iro6 (r905); 57 C. J. S. 495 (1949).

2 United States v. Munsey Trust Co., 332 U.S. 234 (I948); United States use of Hill v. American Surety Co., 200 U.S. I97 (I906); Hutchinson v. Kreuger, 34 Okla. 23, I24 Pac. 59 I (I9I2). The authoritative cases in the different states are collected in this opinion.

${ }^{3} 49$ Stat. 793 (I935), 40 U.S.C.A. 2700 (I943). Section 2 of this Act provides that a contractor with the United States must furnish a bond for the protection of persons supplying labor and materials in prosecution of work provided for in the contract and that on failure of the contractor to pay any subcontractor, the United States may sue for the use of such beneficiaries. "The sole purpose of this act is to protect the subcontractor." United States v. Biggs, 46 F. Supp. 8 (Ill., I942). Many of the states have enacted similar statutes for the purpose of providing those engaged by a public contractor with a substitute for the mechanics' lien. Cases collected in 77 A.L.R. 140 (r932).

4 United States for use of Morgan Co. v. Maryland Gas Co., I47 F. 2 d 423 (C.A. 5 th, I945).

5 Ibid.

${ }^{6}$ Tucker Act, note 12 infra.

${ }^{7}$ Collins v. United States, 93 Ct. Cl. 369 (I94I); Petrin v. United States, 9o Ct. Cl. 670 (I940); N.Y. Shipbuilding Corp. v. United States, 6I Ct. Cl. 357 (I925).

8 United States v. Blair, $32 x$ U.S. $73 \circ$ (I944); Consolidated Engineering Co. v. United States, $98 \mathrm{Ct}$. Cl. 256 (r943); Pneumatic Gun-Carriage Co. v. United States, $36 \mathrm{Ct}$. Cl. $7 \mathbf{I}$ (Igox). 
Unfortunately, both the Court of Claims and the Supreme Court have been content to rest their decisions in this particular field almost wholly upon the precedents at hand, without indicating the rational foundations of their conclusions. It is not surprising, therefore, that when a novel fact situation is presented, obvious conflicts arise between rules habitually applied, clearly revealing that substantial areas of inconsistency underlie views supposedly reconcilable.

Continental Ill. Nat. Bank \& Trust Co. of Chicago v. United States ${ }^{9}$ was the latest of three recent cases raising a problem never encountered previously by the Court of Claims. A contractor with the government for work on a housing project entered into several subcontracts. As in the earlier two cases referred to, ${ }^{\text {ro }}$ each of these subcontracts provided that neither the contractor nor the subcontractor would be held responsible to each other for any damage or delay caused by the government. When subsequent delays and other breaches of contract by the government caused additional expenses to the subcontractors, their claims were included as items of damage in a suit by the prime contractor ${ }^{\text {II }}$ against the United States. The government thereupon presented a motion to omit any findings relating to these claims on behalf of subcontractors, and this motion was granted by the court in a three-to-two decision.

In accordance with their two earlier decisions, the majority of the court held that there existed no basis for the contractor's claim for compensation from the government for the extra expenses incurred by subcontractors. The statutory basis for contractual liability of the United States in any instance is the Tucker Act, $^{\mathrm{I2}}$ in which Congress has provided that the United States shall be liable for claims "founded upon any express or implied contract with the United States." The court reasons that since this Act has application in this case only to the claims of the contractor, any claim by him in behalf of the subcontractor must be founded upon the assumption that the government's conduct has made the contractor liable in turn to the subcontractor. When the presence of the exculpatory clause precludes that possibility, losses suffered by a subcontractor cannot result in any actual loss to the contractor, and therefore are properly excluded from the consideration of damages for which the government is liable.

Judge Madden, in the dissent in this case, displays concern over the fact that the position of the majority in this controversy is logically inconsistent with its past views in respect to treatment of claims in behalf of subcontractors. He observes that the court has customarily admitted these claims as a matter of course, and with the exception of the other two exculpatory clause cases, has consistently ignored the issue of the liability of the contractor to the subcon-

9 8 F F. Supp. 596 (Ct. Cl., r949).

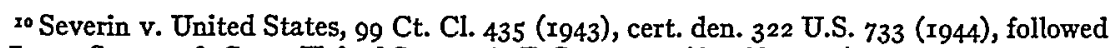
in James Stewart \& Co. v. United States, 63 F. Supp. 653 (Ct. Cl., I946).

"x The suit was actually by the executor under the last will of the contractor, A. N. Severin, deceased.

${ }^{{ }_{2}}{ }_{3} 6$ Stat. I ${ }_{3} 6$ (IgII), 28 U.S.C.A. I49r (I948).

${ }_{3}$ Ibid., at subsection (4). 
tractor. ${ }^{{ }^{4}}$ However, the Judge points out, even in the absence of a contractual provision that the contractor is not to be held responsible for damages caused by the government, such as appeared here, it was frequently the case that for various reasons the contractor was not in fact liable to the subcontractor. Nevertheless, in the entire history of the Court of Claims, recovery on behalf of a subcontractor was never before barred upon this ground.

This observation throws before the court an ambiguity latent in a half-century of its decisions. If the court has considered the issue of the contractor's liability to the subcontractor only in instances in which the exculpatory clause has appeared, ${ }^{55}$ then the failure to extend its analysis to the nonexculpatory clause cases demonstrates a basic inconsistency. Either there exists some implicit theory of governmental liability other than that based upon the contractor's right to anticipated damages, or there has been an unfortunate neglect on the part of the court in many cases to examine the bases of the claims against the government.

Judge Madden's suggestion is that the ambiguity be resolved in favor of a more general theory of recovery under claims in behalf of subcontractors. $\mathrm{He}$ believes that a consistent attitude would be to ignore in all cases the liability or nonliability of the contractor to the subcontractor, and instead treat the contractor as "the owner of a right to have the government comply with its contract, which right he holds in trust for those whom he brings into the situation by giving them interests in such compliance as subcontractors."

Cited as supporting his argument is a recent Supreme Court decision, United States v. Blair..$^{\mathrm{I7}}$ In that case, the Court admitted the subcontractor's losses as items of damage while expressly noting in the opinion that there existed no finding that the contractor was liable to the subcontractor. It was asserted further that the contractor's agreement with the government for certain services "necessarily implies the right to recover extra costs and services wrongfully demanded of respondent under the contract, regardless of whether such costs were incurred or such services were performed personally or through a subcontractor." ${ }_{\mathrm{I} 8}$ This dictum goes even further than Judge Madden's dissent, proposing not merely that

14 Chief Judge Whaley, dissenting in Severin v. United States, 99 Ct. Cl. 435, at 444 (I943), observed, "For fifty years it has been the settled doctrine of this court that a contractor could bring suit for himself and his subcontractor for losses occasioned by delay by the defendant [the United States]. In innumerable cases from Stout, Hall \& Bangs v. United States, $27 \mathrm{Ct}$. of Claims 385 , to Consolidated Engineering Co. v. United States ..., this doctrine has been uniformly followed and never been questioned. ..."

15 The single exception is found in Pneumatic Gun-Carriage Co. v. United States, $36 \mathrm{Ct}$. Cl. $7 x$ (I9OI). The government defended against the claim on behalf of the subcontractor on the ground that the contractor had not yet paid damages to the subcontractor and therefore had suffered no loss. The court noted that there was "nothing hypothetical or remote ... in the amounts that the subcontractor can claim of plaintiff," and held the government immediately liable on the claim.

${ }^{26}$ Continental III. Nat. Bank Co. v. United States, 8I F. Supp. 595, 599 (Ct. Cl., I949).

${ }^{I 7} 32$ I U.S. 730 (I944). $\quad{ }^{88} \mathrm{Ibid}$., at $737-38$ (italics added). 
a court consider immaterial the factor of liability between contractor and subcontractor, but maintaining that the very existence of the subcontractual relationship be ignored in determining the government's liability.

Despite the apparent fairness in refusing to allow a fortuitous circumstance, the contractor's hiring of subcontractors, operate to reduce the government's liability, neither Judge Madden's dissent, nor the decision and dictum of the Blair case, presents a sound basis of recovery. In viewing the problem as one of not permitting the party who broke the contract to escape liability, both opinions apparently disregard the accepted proposition that an action does not lie against the sovereign except by consent. ${ }^{9}$ The privilege of suing the United States is one which can be granted by Congress alone, and no court has the power to extend the government's liability beyond the bounds indicated by legislative mandate. ${ }^{20}$ The Tucker Act ${ }^{2 x}$ allows claims against the United States founded on contract, but such a claim must be based upon an actual loss ${ }^{22}$ by a party to whom the government owed a duty to comply with its promises.23 Neither Judge Madden nor the Supreme Court indicates any basis under which such a duty can be claimed to exist. ${ }^{24}$ The Judge's suggestion that the right against the government is held "in trust" by the contractor for the subcontractor begs the ultimate question. ${ }^{25}$ The erection of a constructive trust in this

x9 United States v. Shaw, 309 U.S. 495, 500 (I940); Commissioners of the State Ins. Fund v. United States, 72 F. Supp. $549\left(x_{947)}\right.$, contains a brief historical outline of the doctrine from its British origin to its most recent legislative encroachment in the United States (the Federal Tort Claims Act). For some recent criticism of the doctrine, cf: Governmental Immunities-A Study in Misplaced Solicitude, 16 Univ. Chi. L. Rev. $x_{28}$ (1948).

20 United States v. Michel, 282 U.S. 656,659 (I93I); Eastern Transportation Co. v. United States, 272 U.S. 675,686 (r927); Price v. United States, 174 U.S. 373,376 (I8g9).

${ }^{2}$ Note I2 supra.

22 The United States is not subject by the Tucker Act to suits for nominal damages. See Severin v. United States, 99 Ct. Cl. 435, 443 (1943), cert. den. 322 U.S. 733 (I944); Great Lakes Construction Co. v. United States, 95 Ct. Cl. 479, 502 (I942); Nortz v. United States, 294 U.S. 3I7, 327 (I935). Nor can more than compensation for damages actually sustained by the party ever be awarded against the United States. See United States v. Smith, 94 U.S. $2{ }_{4}(1876)$.

23 The statute has been strictly construed by the courts, and it has been established that the contract must be one actually contemplated by the parties, that is, at the very least, a contract implied in fact, and not merely a quasi-contract or construction by the court. Braun v. United States, 46 F. Supp. 993 , 98 Ct. Cl. 176 (I942).

24 It has been suggested that the exculpatory clause should be considered irrelevant on the issue of recovery, since it was inserted by the contractor and subcontractor for the sole purpose of protecting themselves, rather than in any way affecting the liability of the government. 34 Minn. L. Rev. I43 (I950), I Mercer L. Rev. II 7 (I949), both noting Continental Ill. Nat. Bank Co. v. United States, 8 I F. Supp. 595 (Ct. Cl., I949). However, the same fallacy exists in respect to this suggestion; if the contractor is not in fact liable to the subcontractor, then, regardless of the intent of the parties, the contractor has no basis upon which he can maintain an action for the losses occurring to the subcontractor.

25 Compare N.Y. Shipbuilding Corp. v. United States, 6r Ct. Cl. 357 (I925). A subcontract expressly provided that all benefits under the government contract were to be held 
instance is merely another way of saying that the United States should be liable. It assumes the conclusion by indicating an appropriate remedy ${ }^{26}$ without argument justifying the cause of action. If the government is to be held liable for the damages incurred by the subcontractor, it must be under some legal theory demonstrating the actual responsibility of the government for its promises in the prime contract.

Section 90 of the Restatement of Contracts provides:

A promise which the promisor should reasonably expect to induce action or forbearance of a definite and substantial character on the part of the promisee and which does induce such action or forbearance is binding if injustice can be avoided only by enforcement of the promise.

An investigation of the theory underlying this section as it is applied reveals its applicability to the problem of the Continental Ill. Bank case.

The recent cases incorporating the doctrine of Section 90 demonstrate a trend toward increasing recognition of what writers have asserted is the fundamental basis of the historic law of simple contracts. ${ }^{27}$ Although "promissory estoppel" (as it has been termed in its modern formulation) has been held by some courts to extend only to charitable subscription cases, ${ }^{28}$ an increasing number of decisions have applied the doctrine to situations of a commercial character. ${ }^{29}$

Judge Madden's belief that the government ought not to be able to disregard its promises to the detriment of the subcontractor can be expressed in the language of the Restatement. Certain sections of the prime contract involving promises of the government induced action ${ }^{30}$ of a definite and substantial char-

"exclusively in trust" for the plaintiff. The court in this case rejected the notion that this provision acted to create in the plaintiff any rights against the United States, and refused to allow his claim.

${ }^{26}$ See the dissenting opinion in Severin v. United States, 99 Ct. Cl. 435,445 (I943), cert. den. 322 U.S. 733 (r944).

${ }^{27}$ I Williston, Contracts $\$$ I39 (1936); Sharp, Promissory Liability, 7 Univ. Chi. L. Rev. 250, 256 (I940); Sharp, Williston on Contracts, 4 Univ. Chi. L. Rev. 30, 32 (I936); Willis, What is Consideration in the Anglo-American Law of Contracts?, 72 U. of Pa. L. Rev. 245, 376 (1924); Plucknett, A Concise History of the Common Law 602-607 (4th ed. I948).

${ }^{28}$ James Baird Co. v. Gimbel Bros., 64 F. 2d 344 (C.A. 2d, I933); Quincy Arbitrage Corp. v. Cities Service Co., I56 N.Y. Misc. 83, 282 N.Y. Supp. 294 (I935); Comfort v. McCorkle, I49 N.Y. Misc. 826, 268 N.Y. Supp. I92 (I933).

${ }^{29}$ Goodman v. Dicker, I69 F. 2d 684 (App. D.C., x948); Northwestern Engineering Co. v. Ellerman, 69 S.D. 397, ro N.W. 2d 879 (I943); Lusk-Harbison-Jones, Inc. v. Universal Credit Co., I64 Miss. 693, I45 So. 623 (I933); Port Huron Mach. Co. v. Wohlers, 207 Iowa 826, $22 \mathrm{I}$ N.W. 843 (I928); see Robert Gordon, Inc. v. Ingersoll-Rand Co., II7 F. 2d 654, 65I (C.A. 7 th, I94I).

${ }^{30}$ The action induced was twofold: first, the subcontractor entered into an agreement with the contractor, and, second, he prepared to meet his duties under the subcontract. Section 90 applies even when the action fulfills a pre-existing duty. Iuther v. National Bank of Commerce, 2 Wash. 2d 470, 98 P. 2d 667 (I940), noted, I6 Wash. L. Rev. 49 (I94r). 
acter on the part of the subcontractor. ${ }^{3 \mathrm{I}}$ There can be no doubt that the government contracting officer reasonably anticipated that the subcontractor would take such action. ${ }^{32}$ Furthermore, leaving the subcontractor helpless against damaging breaches of contract by the government under these circumstances results in obvious injustice.

An apparent objection to the application of the promissory estoppel doctrine in this case lies in the fact that the subcontractor was not the party to whom the promises were formally addressed, which would appear to be required by the use of the term, "promisee," in Section go. However, there is no indication in any of the cases relying upon promissory estoppel that the use of this term so restricts the applicability of the doctrine. ${ }^{33}$ On the contrary, the courts have often stated the doctrine in most general terms, 34 while not a single case has

${ }^{3 x} \mathrm{~A}$ stipulation in the prime contract denying the existence of contractual relations with any subcontractors (note 32 , infra) does not make the subcontractor's reliance on the government's promises any less justified. Subcontractors had always previously received compensation for damages despite the alleged absence of a contractual relationship with the government (note 8, supra). Analogous are cases in which employees were allowed to recover on bonus promises which the promisor expressly stipulated should impose no liability upon him. See cases and authority in Fuller, Consideration and Form, 4I Col. L. Rev. 799, 8II n. I6 (I94I). In Hollerbach v. United States, 233 U.S. I65 (I9I4), and United States v. Atlantic Dredging Co., 253 U.S. I (r920), contractors who had been misled by the representations of a government officer were granted relief in spite of warnings in the contract not to rely on them.

${ }^{32}$ The Court of Claims has long recognized that the government is aware of the fact that subcontractors will usually be employed on federal projects. Pneumatic Gun-Carriage Co. v. United States, $36 \mathrm{Ct}$. Cl. $7 \mathrm{I}$ (I9OI). In the Continental Ill. Bank case the following provisions of the prime contract leave no room for doubt that the government had complete knowledge as to the identity of the subcontractor and the exact action he would take in exposing himself to loss through the government's breaches of contract:

"Sec. 28, Subcontracts:

"x. The Contractor shall not award any work to any subcontractor without prior written approval of the Contracting Officer, and the terms of all subcontracts shall be subject to the prior approval of the Contracting Officer.

"3. The Contractor shall cause appropriate provisions to be inserted in all subcontracts relative to the work to bind subcontractors to the contractor by the terms of the General Conditions and other Contract Documents insofar as applicable to the work of subcontractors....

"4. Nothing contained in the Contract Documents shall create any contractual relation between any subcontractor and the Government."

About this fourth clause, the majority opinion said, "A mere statement that a contractual relation did not exist would be ineffective if all the elements of such a relation were otherwise present." Continental Ill. Nat. Bank Co. v. United States, 8I F. Supp. 596, 598 (Ct. Cl., I949).

33 In Hanna State \& Savings Bank v. Matson, 53 Wyo. I, 77 P. 2d 621 (x938), the court held the defendant liable under Section 90 where his conduct constituted an implied promise which was relied upon by a third party; in Dickerson v. Colgrove, 100 U.S. 578 (I879), a mortgagee was estopped from asserting his claim because of reliance by a third party upon a communication by the mortgagee to his sister.

34 Judicial Recognition of the Promissory Estoppel Section in the Contracts Restatement, $36 \mathrm{III}$. L. Rev. 187,203 ( $\mathrm{r} 94 \mathrm{I})$. "[H]e who by his language or conduct leads another to do what he would not otherwise have done, shall not subject such person to loss or injury by disappointing the expectations upon which he acted." Goodman v. Dicker, I69 F. 2d 684, at 685 (App. D.C., r948), quoting from Dickerson v. Colgrove, roo U.S. 578 (I879). 
been found insisting upon the formal construction of the word, "promisee." The discussion before the American Law Institute concerning the original draft of Section $g \circ$ further indicates that what was primarily desired was that both the identity of the party relying on the promisor's statement and the manner and extent of the reliance should be circumstances within the reasonable expectation of the promisor. ${ }^{35}$ These conditions clearly were met by the facts of the instant case, and it is difficult to see, under the language and policy of Section go, why the government should not be accountable for its promises.

Closely analogous is the case in which a change of position in reliance by a third party makes his right upon a promise for his benefit indefeasible. ${ }^{6}$ The contractor, as promisee, owes duties to the subcontractor arising out of their contract which coincide with certain promises of the government in the prime contract. In reliance upon the government's promises, the subcontractor changes his position and suffers a loss in consequence. The subcontractor then, as a creditor beneficiary ${ }^{37}$ of the prime contract, has a direct enforceable right against the government to the promised performance, and is entitled to damages for breach of contract. ${ }^{8}$ This conclusion has even stronger appeal in the Continental Ill. Bank case, where the subcontractor, relying upon his usual derivative right against the government, waived his rights against the promisee by stipulation in the subcontract. Of course, if it were found that there was manifest in the prime contract an intent to confer a benefit ${ }^{39}$ upon the subcontractor, there would be no question of his right under it as a donee beneficiary..$^{\circ}$

${ }^{35}$ American Law Institute, Proceedings, Vol. IV Appendix, at 85 et seq.

${ }^{36}$ Only after a stranger to a contract has changed his position in reliance upon it, the parties to the contract being aware he was so doing, can he have it enforced, but not, however, in virtue of any right he acquired by force of it, but on the new and independent equity springing from their conduct and his action induced by it. Crowell v. Currier, I27 N.J. Eq. (I 2 C. E. Green) 152 , 156 (1876); Barringer v. Fidelity \& Deposit Co. of Md., r6r S.C. 4, 159 S.E. 373 (I93I); Morstain v. Kircher, I9o Minn. 78, 250 N.W. 727 (I933); Rest., Contracts $\S$ I $_{43}$ (I932); 2 Williston, Contracts $\$ 397$ (1936).

37 "That person is a creditor beneficiary if no purpose to make a gift appears from the terms of the promise ... and performance of the promise will satisfy an actual, or supposed, or asserted duty of the promisee to the beneficiary, ..." Rest., Contracts $\S$ I33(I)(b) (I932).

${ }^{8} 8$ Plaintiff, who had delivered materials to the government on order of a subcontractor, held qualified to sue as a third party beneficiary under the contract between the contracting officer and the United States. The contract made the government liable for such unliquidated claims as the contractor may have in good faith incurred in connection with the work. Maneely, Adm'r v. United States, $68 \mathrm{Ct}$. Cl. 623 (r929). See Nemmers, The Problem of Government Liability to Sub-contractors Under Terminated CPFF Prime Contracts-The Third Party

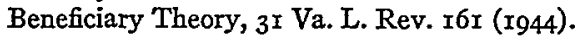

${ }^{39} \mathrm{An}$ "intent to benefit" means merely that there is an expectation that another will receive some future advantage from the particular performance. However, courts have been neither clear nor consistent in their use of these terms. Nair, Intent and Benefit in Third Party Beneficiary Cases, I Conn. Bar J. 94 (I927).

$4^{\circ}$ Rest., Contracts $\S \mathrm{I}_{33}$ (I)(a) (I932); 2 Williston, Contracts $\S 356,357$ (I936); United States v. Morley Construction Co., 98 F. 2 d 78I, 788-89 (C.A. 2d, 1938) (laborers hired by subcontractor held to be "donee beneficiaries" of stipulation in prime contract between United States and contractor that wages should not be less than prevailing rate). 
The United States is liable, under the Tucker Act, only for claims founded on contract. ${ }^{4^{1}}$ Under third-party-beneficiary doctrine, the necessary consideration for the government's promise is provided by the contractor. However, if promissory estoppel is applied, the validity of the contractual relationship between the contractor and the United States may be disregarded..${ }^{2} \mathrm{~A}$ contract is merely a promise, the performance of which the law recognizes as a duty, and for breach of which a remedy is given. ${ }^{43}$ The promises in the prime contract are not implied; 44 they are express promises, made enforceable under Section 90 by the subcontractor's reasonably anticipated reliance, and are thus within the statutory requirement for governmental liability.

Since, as has been pointed out, the contractor's claim against the United States is effectively barred, 45 the enforceable right against the government lies solely with the subcontractor. It is therefore the latter who should properly bring the action in the Court of Claims. ${ }^{4}$ Although the courts often indulge in dictum to the effect that a subcontractor may not bring suit against the government, 47 the authority usually cited for this proposition is clearly distinguishable in the case of actions relying on promissory estoppel. $4^{8}$

The doctrine of consideration has often been the object of attack by legal authorities.49 Section 90 , whether another weapon of attack or a "safety valve"

4 Note 12, supra.

42 While the validity of the prime contract is not questioned in the Continental IIl. Bank case, it has occasionally happened that a subcontractor has suffered losses due to cancellation of the subcontract as a consequence of the government's cancellation of the prime contract. Promissory estoppel not having been considered in these cases, with the prime contract no longer in existence, the subcontractors were held to be without a remedy against the government. Kal Machine Works, Inc. v. United States, 68 F. Supp. 436 (Ct. Cl., I946); Precision Metal \& Machine Co. v. United States, 68 F. Supp. 437 (Ct. Cl. I946).

13 Greiner v. Greiner, I3I Kan. 760, 764, 293 Pac. 759, 762 (I930); Port Huron Mach. Co. v. Wohlers, 207 Iowa 826, 829, 22 r N.W. 843, 844 (r928); American Law Institute, Proceedings, Vol. IV Appendix, at 94 (Williston).

44 Note 23, supra.

45 Note 22, supra.

${ }^{46}$ Federal Rules of Civil Procedure, Rule I7(b) (1938); Clark, Code Pleading $\$ 22$ (1947).

17 United States v. Blair, 32x U.S. 730 (r944); Continental Ill. Nat. Bank Co. v. United States, 8 I F. Supp. 596 (Ct. Cl., I949).

${ }^{8}$ Merritt v. United States, 267 U.S. 338 (1925), usually cited as Supreme Court authority for the proposition that a subcontractor cannot sue the United States, actually decided only that when a contractor fraudulently induces a subcontractor to release his subcontract for an amount less than that to which he is entitled, the subcontractor has no recourse against the government. The loss to the subcontractor in this case occurred because of reliance on statements made by the contractor, and no promises of the government were involved. Though the Supreme Court, in United States v. Blair, 32I U.S. 730 (I944), apparently accepted on faith for purposes of dictum the lower court's citation of the Merritt case, it never has actually passed upon the issue itself.

49 Sharp, Pacta Sunt Servanda, 4r Col. L. Rev. 783 (I94I); Willis, What is Consideration in the Anglo-American Law of Contracts?, 72 U. of Pa. I. Rev. 376, 39I et seq. (I924); Shattuck, Gratuitous Promises-A New Writ?, 35 Mich. L. Rev. 908 (1937); Pound, Law 
which will prevent the rest of the doctrine from falling into impossible inconsistency,,$^{\circ}$ tends to emphasize reliance as a determining factor in the enforcement of promises, rather than "bargained-for" and "agreed upon" detriment or benefit. ${ }^{5}$ In this respect, the development is not unlike that of "deceit" notions in the field of torts. ${ }^{2}$ Both have arisen in response to modern notions of fairness, which in many instances are incompatible with the strict rule of consideration. The initial reaction to fact situations such as that presented by the Continental Ill. Bank case is generally one favoring recovery for the subcontractor, primarily because of the reasonable foreseeability of the reliance and resulting damage. The law probably serves its function better when it conforms to such prevailing notions of fairness.

Nevertheless, the re-emergence of the reliance principle of enforcing promises has met with the inertia of the courts, and there is at least some doubt today as to whether even a court which recognizes the general applicability of Section go would care to hold that its protection may extend to third parties, as has been here suggested. However, as neither the policy underlying promissory estoppel nor the cases upholding it preclude such an application of the doctrine, there is considerable likelihood of its development in the direction indicated. Of course, in regard to the specific problem of providing protection for the subcontractor, the preferable alternative would be action by Congress further narrowing governmental immunity, at least in respect to subcontractors' claims for damages.

\section{MATERIAL WITNESSES AND "INVOLUNTARY" CONFESSIONS}

Confessions secured through the commitment of persons as material witnesses for "John Doe" proceedings may test the extent to which the Supreme

and Morals 40 (r924); Lorenzen, Causa and Consideration in the Law of Contracts, 28 Yale L. J. $62 x, 643-46$ (r9xg); Ballantine, Is the Doctrine of Consideration Senseless and rllogical?, II Mich. L. Rev. 423 (IgI3).

${ }^{50}$ American Law Institute, Proceedings, Vol. IV Appendix, at II 2.

5x For analogous development in England of enforcement of promises on the basis of detrimental reliance, see Unger, The Twilight of Consideration, I4 Solicitor 76 (I947).

52 There has been gradual relaxation of the requirement that subjective intent to deceive must be an element of a cause of action in deceit. Judicial Recognition of the Promissory Estoppel Section in the Contracts Restatement, 36 Ill. L. Rev. $x 87$, x96 n. 43 (I94r). It has been suggested that promissory estoppel is a principle influencing both torts and contracts and should not be categorized as belonging to either. Ibid., at 203;80 U. of Pa. L. Rev. 594 (1932), noting Saunders v. Galbraith, 40 Ohio App. 155, I 78 N.E. 34 (I93I). Indeed, the doctrine bears a striking resemblance to the action sounding in tort given at early common law for nonperformance of a promise which another had relied upon to his detriment. Willis, Consideration in the Anglo-American Law of Contracts, 8 Ind. L. J. I53, I59 (I932); Ames, The History of Assumpsit, 2 Harv. I. Rev. I, I5 (x888).

A modern view favoring extension of the application of tort principles to such cases of "nonfeasance" is excellently presented in Liability in Tort for the Negligent Nonperformance of a Promise, 45 Harv. L. Rev. I64 (193I), and this view is applied in respect to a well known contracts case, in 82 U. of Pa. L. Rev. 648 (I934), noting Comfort v. McCorkle, I49 N.Y. Misc. 826, 268 N.Y. Supp. I92 (I933). 